\title{
Seamounts, plateaus and governance issues in the southwest Indian Ocean, with emphasis on fisheries management and marine conservation, using the Walters Shoal as a case study for implementing a protection framework
}

\author{
Marsac Francis ${ }^{1,}{ }^{*}$, Galletti Florence ${ }^{1}$, Ternon Jean-Francois ${ }^{1}$, Romanov Evgeny V. ${ }^{2}$, \\ Demarcq Herve ${ }^{1}$, Corbari Laure ${ }^{3}$, Bouchet Philippe ${ }^{3}$, Roest Walter ${ }^{4}$, Jorry Stephan ${ }^{4}$, Olu Karine ${ }^{5}$, \\ Loncke Lies ${ }^{6}$, Roberts Michael J. ${ }^{7,9}$, Ménard Frédéric ${ }^{8}$
}

\author{
${ }^{1}$ MARBEC, IRD, Univ Montpellier, CNRS, Ifremer, Sète, France \\ 2 CAP RUN - CITEB, Le Port, Île de la Réunion, France \\ ${ }^{3}$ Muséum National d'Histoire Naturelle, Institut de Systématique Évolution Biodiversité (ISYEB, UMR \\ 7205), MNHN, CNRS, Sorbonne Université, EPHE, 57 Rue Cuvier, CP 51, 75005, Paris, France \\ ${ }^{4}$ Ifremer, Unité Géosciences Marines, CS 10070, 29280, Plouzané, France \\ 5 Ifremer, Unité Etude des Ecosystèmes Profonds, CS10070, 29280, Plouzané, France \\ ${ }^{6}$ Centre de Formation et de Recherche sur les Environnements Méditerranéens, UMR 5110 UPVD \\ CNRS, Perpignan, France \\ ${ }^{7}$ Ocean Science Campus Nelson Mandela University, Port-Elizabeth, South Africa \\ ${ }^{8}$ Aix-Marseille Univ, Université de Toulon, CNRS, IRD, MIO, Marseille, France \\ ${ }^{9}$ National Oceanography Centre, European Way, Southampton, United Kingdom \\ *Corresponding author : Francis Marsac, email address : francis.marsac@ird.fr
}

\begin{abstract}
:
There is a growing interest in the management of seamounts of the South Western Indian Ocean (SWIO) both in waters under national jurisdictions and in the Areas Beyond National Jurisdiction (ABNJ). On the one hand, new scientific knowledge has been gathered through various oceanographic cruises during the past decade and, on the other hand, new agreements are under consideration globally to promote conservation and sustainable use of the biodiversity in the ABNJ, where the deep sea ecosystems associated to seamounts are a growing matter of concern. SWIO seamounts have attracted interests from fishing operators since the 1960s, while mining exploration contracts have been recently granted. Seamounts are known to shelter rich, fragile and poorly resilient ecosystems whose important ecological functions that are threatened by various anthropogenic pressures. While many seamounts and shoals are located in national waters, many others fall in the ABNJ with no current legal status per se. To ensure conservation of their habitats and biodiversity, it is essential that protection measures are instigated under an internationally-recognized legal and institution framework. In this paper, we review the current state of such a framework relevant to seamounts, with emphasis on fisheries and conservation in the SWIO. We select an emblematic seamount, the Walters Shoal, as a case study to discuss how this site could become a fully-protected space in the ABNJ. Since a large part of the SWIO is under the mandate of the Nairobi
\end{abstract}


Convention (Regional Sea under the auspices of UNEP), guidelines are proposed to spur a dedicated seamount governance in the framework of this Convention.

Keywords : International Law of the Sea, Vulnerable Marine Ecosystems, deep-sea fisheries, deep-sea mining, benthic biodiversity, Saya de Malha Bank, South Indian Ocean Fisheries Agreement, Areas Beyond National Jurisdiction, Amended Nairobi Convention, Marine Protected Areas. 


\section{1- Introduction}

54 Seamounts are usually described as steep topographic rises of the seabed with an elevation 55 greater than $1000 \mathrm{~m}$ (IHO, 2008) and a limited area across the summit (Rogers, 1994; Yesson 56 et al., 2011, Clark et al., 2011). Seamounts in an ecological sense also include knolls and hills 57 rising only a few hundred meters (200-1000 m) above the basal depth (Clark et al, 2007; 
Rogers 2018). They usually represent active or extinct volcanoes located on underwater plateaus, mid-oceanic rifts or intra-plate hot spots. Estimates of seamount numbers have varied by orders of magnitude, depending on the data resolution and on the extrapolation method used. In the Western Indian Ocean, west of $80^{\circ} \mathrm{E}$ (FAO area 51), the number of seamounts with an elevation of $\geq 1000 \mathrm{~m}$ above the seafloor has been estimated at 2559 , of which 820 are located within Exclusive Economic Zones (EEZs) (Yesson et al, 2011). In the South Western Indian Ocean region (SWIO), the seamounts are distributed along the South West Indian Ridge (SWIR, 7700 km from Bouvet Island to Rodriguez triple junction, Sauter \& Cannat, 2010), along the Mid-Indian Ridge, on the Mozambique Plateau, on the Madagascar Ridge, a rise which extends over $1100 \mathrm{~km}$ south of Madagascar, and in the Mozambique Channel (Courgeon et al., 2016). The submarine plateaus and seamounts of the SWIO originate from a multi-phase history of the Indian Ocean opening and dislocation of the Gondwana supercontinent which began in the early Jurassic (around 180 million years ago). It is noteworthy that the vast majority of seamounts in the SWOI $(68 \%)$ are located in international waters, beyond national jurisdiction of States (200-nautical miles ${ }^{1}$ (M) EEZs) (Kitchingman, 2007, Yesson et al, 2011).

Besides the typical seamounts, a characteristic feature of the region is "underwater shoals" that represent submerged shelf areas. Oceanic shoals cover vast shallow areas with depths less than 200 m compared to the limited surface area of seamounts tops. Shoals such as Saya de Malha $\left(8^{\circ} 30^{\prime} \mathrm{S}\right.$ to $12^{\circ} \mathrm{S}$ and $59^{\circ} 30^{\prime} \mathrm{E}$ to $\left.62^{\circ} 30^{\prime} \mathrm{E}\right)$ rise to depths of merely $8-15 \mathrm{~m}$ below the surface. Saya de Malha is the northern part of the Mascarene Plateau stretching from the north of Mauritius to the Seychelles (Fig. 1).

Because of their magmatic origin, seamounts contain mineral resources. A crust of ferromanganese oxide enriched with cobalt, copper, manganese and sulphur has accumulated

\footnotetext{
${ }^{1} \mathrm{M}$ stands for nautical mile, with 1 nautical mile $=1852 \mathrm{~m}$
} 
around the oldest reliefs (Wessel, 2007; ISA, 2007). It is estimated that these reserves could exceed those on the continents, but presently the extraction cost remains prohibitive to be economically profitable. However, the situation could change in the coming decades as similar resources on the continents become more and more scarce.

Seamounts are also renowned to be particular habitats for a range of rare and fragile species and are thus qualified as biodiversity hotspots (Worm et al., 2003; Morato et al., 2010; Clark et al., 2010). The dominant large fauna on many seamounts is composed of benthic organisms (corals, sponges) which are particularly species-rich and at the origin of high habitat heterogeneity and biodiversity for associated fauna (Buhl-Mortensen et al.., 2010). Such species belonging to deep-sea corals and sponges have been designated as indicator species to characterize Vulnerable Marine Ecosystems (VME) because of their sensitivity to bottom fishing impacts (FAO, 2009). Although historical records of bentho-pelagic fauna do exist, from sporadic explorations during the first 60 years of the $20^{\text {th }}$ century, the fauna inhabiting the SWIO seamounts is still poorly known. The lack of knowledge about structure, function and connectivity of seamount ecosystems requires intensive scientific efforts to better assess the threats to seamount resources from fishing and seabed mining (Clark et al., 2012). Seamounts serve as habitat for a large number of VME indicator species (Watling \& Auster, 2017), leading these authors to propose that seamounts should be managed as VMEs. The exploitation of fisheries resources associated to seamounts form part of the competence of the Southern Indian Ocean Fisheries Agreement (SIOFA) which regulates some aspects of bottom fishing activities to minimize impacts on the benthic ecosystem and manage deep-sea fisheries.

Several seamounts are also marine landmarks for migrating pelagic species at different stages of their life cycle. The Walters Shoal is a foraging destination for Barau's petrel (Pterodroma baraui) an endemic seabird of Reunion Island that flies here during the breeding 
season (Pinet et al., 2012). Humpback whales (Megaptera novaeangliae) were reported around the Walters Shoal, either by direct sightings (Collette \& Parin, 1991; Best et al., 1998), or by satellite tagging (Cerchio et al., 2016; Trudelle et al., 2016). Humpback whales also congregate during winter for breading along the slopes of the La Perouse seamount, located northwest of Reunion Island (Dulau et al., 2017). Acoustic-based experiments carried out in the Pacific showed that whales can take advantage of enhanced foraging opportunities at seamounts (Johnston et al., 2008).

Because of their mineral resources and their biological abundance and richness, seabed mining and bottom trawling put at risk the benthic ecosystem. Mining can cause irreversible destruction of habitats, noise pollution, and contamination by toxic metals, oil and chemicals, with potential biological impacts (reproduction, larval health...). As several exploited species have high longevity with slow growth and late maturity (K-strategy species), their resilience to fishing pressure is very low making their stocks highly vulnerable (Morato and Clark, 2007;Clark et al., 2019) and susceptible to become overfished in the absence of appropriate management measures (Clark, 2009). The orange roughy, an often-cited example, has a life span of over 100 years and a maturity around 20 years. Their fisheries worldwide have proven to be non-sustainable (Roberts, 2002; Sissenwine and Mace, 2007; Picher et al., 2010). Whilst this is of great concern, a few seamount fish species and others that aggregate over seamounts (Morato and Clark, 2007) are relatively short-lived and fast-growing, such as the rubyfishes (Emmelichthyidae) or certain lanternfishes (Myctophidae).

Although no established deep mining activities occur nowadays (only prospection), the legal protection in the form of a governance framework to regulate possible future exploitation of these features is quasi nonexistent. Ecosystem monitoring would be necessary to ensure that all kinds of possible activities on the seamounts do not jeopardize their ecosystem. Seamounts in ABNJ are of particular matter of concern and form part of ongoing 
discussions at the international level (https://www.un.org/bbnj/). The growing corpus of knowledge that is being acquired on seamounts could help to expand and strengthen the few management actions taken so far by regional organizations, to warrant the conservation of these sensitive and complex ecosystems (Garcia et al., 2013).

With this background, the goal of this paper is therefore to integrate scientific information and the current status of the management of natural resources at SWIO seamounts to formulate possible recommendations for the protection of seamounts habitats and ecosystems in the ABNJ of the SWIO. We illustrate the various issues and challenges of seamount governance in the ABNJ by using the Walters Shoal, a very shallow seamount $(18 \mathrm{~m})$ located at $43^{\circ} 54^{\prime} \mathrm{E} / 33^{\circ} 12^{\prime} \mathrm{S}$, as a case study, on the basis on advanced ecological knowledge collected on this particular seamount. Eventually we suggest guidelines for an evolution in the legal aspects related to seamounts in the SWIO within the framework of the Amended Nairobi Convention.

\section{2- Current management of seamounts}

\subsection{Current principles of marine governance}

Whereas a seamount exists as an entity and is so recognized in natural sciences, a seamount has no specific existence per se under the United Nations Convention on the Law of the Sea (UNCLOS). A more general legal framework applies to it. The legal status of a seamount depends on its location relative to the different maritime zones that have been established by the UNCLOS. In the Territorial Sea, which extends $12 \mathrm{M}$ from the baseline (coastline), the human activities are governed by the laws and regulations of the coastal state. In the EEZ, extending to a distance of $200 \mathrm{M}$ from the baseline, each coastal state has exclusive rights to exploit natural resources from the water column (e.g. pelagic fish) and from the seabed and subsoil (e.g. oil and gas, minerals, demersal and benthic fish stocks), and to grant access to other nations for exploitation. Beyond the $200 \mathrm{M}$ limit starts the so-called 
"high seas", or the ABNJ where no sovereignty can be claimed by any State, with regard to the water column. However, regulation applies to fishing in the ABNJ under the Regional Fisheries Management Organizations (RFMOs) framework.

The continental shelf, defined as the seabed and subsoil of the natural prolongation of the coastal state's land territory under the ocean, is subject to a particular regulation outside the EEZ. When a morphological continuity is scientifically proven from the landmass to the outer edge of the continental margin (beyond the $200 \mathrm{M}$ limit), the coastal state can make a submission to the Commission on the Limits of the Continental Shelf (CLCS) to define the outer limits of its continental shelf beyond 200 M. In most cases, the outer continental shelf is limited to a maximum of $350 \mathrm{M}$ from the coastal baseline but under particular circumstances it can even go beyond. In some cases, topographic features, including seamounts and reefs, are claimed as part of this extension. A recent example shows that such a stake can involve more than a single coastal State. In 2008, Seychelles and Mauritius have agreed to exercise a joint sovereignty of the continental shelf of Saya de Malha, extending beyond the EEZ of the respective two coastal states, which was endorsed by the CLCS in 2011. This extended joint jurisdiction does not concern the water column and the living organisms above the shelf.

Outside the extended continental shelf is the "Area" administered by the International Seabed Authority (ISA) which shall organize and control all mineral-related activities concerning the seabed and the subsoil. According to UNCLOS, these mineral resources are recognized as a common heritage of mankind. For the moment, Indian Ocean seamounts like Walters Shoal, Coral Seamount, Middle of What, Atlantis Bank, Fools Flat still belong to the "Area".

\subsection{Management of mineral exploration in the high seas}

Among all contracts for exploration managed by ISA, 5 out of the 29 entered into force worldwide are located in the Indian Ocean ( 1 for polymetallic nodules, 4 for polymetallic 
sulphides). None of these five contracts concern cobalt-rich ferromanganese crusts (ISA, 2019). Middle of What, Atlantis Bank and other seamounts of the SWIR are of potential interest for polymetallic sulphides. For instance, in 2011, the ISA granted a 15-year contract for the exploration of polymetallic sulphides to the China Ocean Mineral Resources Research and Development Association. This contract covers part of the SWIR and consists of 100 blocks of $100 \mathrm{~km}^{2}$ each, strategically placed along the axial part of the ridge and associated seamounts. It is important to stress that the ISA contracts are, thus far, limited to exploration. The next phase, i.e. the exploitation of marine minerals, may follow, however this remains speculative and is not likely to happen in a near future. Besides mining operations, simpler extractive activities can occur on shallow plateaus, such as the suction dredging of sand and gravel that are most sought-after products for construction work. Nevertheless, issues regarding environmental protection and biodiversity conservation related to extractive purposes beyond national jurisdiction should be considered before any exploitation permit be granted

In that perspective, the ISA Mining Code has provisions to protect the marine environment from the harmful effects of mining. Several Regional Environmental Management Plans (REMP) are under development in regions with exploration contracts. These plans aim to conserve areas of the seabed through a network of large no-mining areas called 'Areas of potential environmental interest' (APEIs). APEIs are designed by scientists to be representative of the full range of habitats, biodiversity and ecosystem structure and functions to be protected. Thus far, a single REMP is in place worldwide, located in the East Pacific (Clarion-Clipperton Zone) (Lodge et al, 2014). In the absence of spatial planning in the Indian Ocean, a workshop specific to this ocean is planned by the ISA to identify APEIs for a future REMP.

\subsection{Deep-sea fisheries management in the Southern Indian Ocean}


Deep-sea fishing grounds are in the bathymetric range 200-1200 m. Highly valuable demersal and benthopelagic fish resources have been harvested at seamounts since the 1970s by bottom or midwater trawling, catching a dozen of species in the Indian Ocean, including orange roughy (Oplostethus atlanticus), alfonsinos (Beryx spp), oreos (Neocyttus rhomboidalis, Pseudocyttus maculatus), cardinalfish (Epigonus spp), rubyfish (Plagiogeneion rubiginosus), southern boarfish (Pseudopentaceros richardsoni), rudderfish (Centrolophus niger), pelagic armourhead (Pseudopentaceros wheeleri), Patagonian toothfish (Dissostichus eleginoides) and bluenose (Hyperoglyphe antarctica) (Romanov, 2003; Clark et al., 2007).

Soviet vessels started to explore deep-sea fishing grounds in the Southern Indian Ocean in the early 1970s with large stern trawlers. These explorations were supported by research surveys and a strict scientific monitoring, demonstrating that seamount resources are limited and associated to fragile stocks (Romanov, 2003). During the 1980s, the annual catches remained below 4000 t. With the introduction of new operators, catches by non-regulated fisheries increased dramatically during the 1990s reaching a peak of $13140 \mathrm{t}$ in 1999 (FAO 2017). Orange roughy dominated the catches during 1998-2006 (range of 2300 to $7500 \mathrm{t}$ ) (Fig. 2). After 2010, alfonsinos catches were the highest (1800-4500 t annually), constituting an average $20 \%$ of the deep-sea fish catches during 2010-2015 (Fig. 2).

Retained by-catch species are also of high value and include several of the species listed earlier. Deep-water demersal sharks (living below $200 \mathrm{~m}$ depth) are another matter of concern, as a by-catch of demersal trawl, mid-water trawl, demersal longline and demersal gillnet gears. These sharks have a very low fecundity and have been rated as extremely vulnerable by ecological risk assessment analyses (Lucena-Frédou et al., 2017; Georgeson et al., 2019). In the SWIO, 112 species of such chondrichthyan species have been reported to interact with the deep-sea gears (Ebert 2013, 2014). Seamount fisheries are generally 
qualified as boom and bust fisheries, thus a swift implementation of management and conservation measures is required.

\subsubsection{The setting up of a deep-sea fisheries management organization}

Seamount governance in the Indian Ocean immediately leads to the issue of fishing, and seamount fisheries deserve a close focus. Fishing pelagic species on a seamount never had any specific regulation. In the $\mathrm{ABNJ}$, pelagic resources are accessible to any fishing nation which must comply with the harvest and management rules of the relevant RFMO, and both seamounts and non-seamounts areas are treated the same way. By contrast, specificities were introduced for deep-sea fishing when the SIOFA (https://www.apsoi.org/), a FAO Regional Fisheries Management Body, came into force in 2012, creating a competent RFMO for bottom-associated species. SIOFA has currently nine Contracting Parties, Australia, the Cook Islands, the European Union, France (on behalf of its Indian Ocean Territories), Japan, Korea, Mauritius, Seychelles and Thailand. Other states not having yet ratified are Kenya, Madagascar, Mozambique and New Zealand. Comoros is one cooperating non-Contracting Party and Chinese Taipei a Participating fishing entity.

The most emblematic initiative relevant to seamounts fisheries in the high seas of the Southern Indian Ocean is a decision taken by private fishing companies to form an association designed to promote responsible fishing and to support effective fisheries management of the species exploited by its members (Shotton, 2006). This initiative was triggered by the lengthy process in establishing the SIOFA (Leroy and Galletti, comm. pers.), and by the worries of some fishing operators that, in the meantime, management issues would remain unaddressed (Shotton, 2006). The Southern Indian Ocean Deepsea Fishers Association (SIODFA) was then created in 2006 by five fishing companies registered in Australia (1), Mauritius (1) and Cook Islands (3). SIODFA members applied to themselves rules concerning a number of seamounts, such as the implementation of 13 voluntary benthic protected areas (BPAs) in the 
high seas within the SIOFA perimeter, with the expectation that these conservation measures would later remain in the scope of SIOFA for a wider legal dissemination. All SIODFA members have been fishing in the South Indian Ocean since 2000, but some undertook deepsea fishing as early as 1996.

The 13 SIODFA-delimited BPAs comprise a total area of $309150 \mathrm{~km}^{2}$ which is less than $1 \%$ of the SIOFA area. BPAs are designed as localized areas of known value and representative benthic biodiversity where no bottom or midwater trawling would be allowed. Hence, they concern only a depth range where trawling is possible. Strictly speaking, such BPAs only concern deep-sea fisheries and the benthic ecosystems, but neither the water column (meso- and epipelagic fauna) nor the seabed for extractive purposes such as mining and/or oil drilling (although damages would affect pelagic and benthic ecosystems). Nevertheless, when the ISA evaluates the seabed mineral activities, relevant fisheries activities and protected areas do need to be taken into account, thus the BPA status can be helpful in a more holistic approach for the conservation of sensitive areas.

\subsubsection{Current status of the SIOFA management}

The SIOFA has adopted 15 binding conservation and management measures (CMM) since 2016. So far, SIOFA has mostly focused on the management of orange roughy and alfonsinos stocks inhabiting seamounts among other major fish species (armourhead, bluenose, dogfish, oreos and patagonian toothfish). The downside is that underwater shoals within the SIOFA area of competence, such as Saya de Malha, have been overlooked. A large fraction of the Saya de Malha Bank is in the ABNJ and supports the largest contiguous seagrass beds in the world. For such characteristic, Saya de Malha was considered by UNESCO as a potential candidate to become a Marine World Heritage site, classified as a site with "Potential Outstanding Universal Value" (Obura et al., 2012). Despite the uniqueness of this underwater shoal, a trawl fishery has been active from 2015 to 2017. Up to 61 Thailand-flagged trawlers 
were active on an area of $33000 \mathrm{~km}^{2}$, performing 4000 trawls per year. The catch declined from 23000 to $10000 \mathrm{t}$ over the first two years collapsing to $2000 \mathrm{t}$ by 2017 (Panjarat \& Boonsripum, 2018). Although the two main species caught, lizardfish (Saurida spp) and round scad (Decapterus spp) are not considered as threatened by the IUCN, the damage created on the benthic ecosystem (corals, sponges, seagrass) is likely to be important and could not be evaluated in a robust manner due to the limited observer coverage rate of $5 \%$. There are ongoing discussions at the SIOFA to define general rules for bottom fishing ${ }^{2}$ in established bottom fishing fisheries, which would apply to the Saya de Malha Bank mixed species fishery. At the $6^{\text {th }}$ Meeting of the Parties in 2019, Mauritius and Seychelles claimed that due to the joint management of Saya de Malha by the two countries, "SIOFA can no longer devise any policy or implement any project in this area". This statement introduces some confusion with respect to the management of living resources associated to the seabed as the rights conferred by the CLCS and the resulting sovereign rights on the extended continental shelf do not apply to living resources other than sedentary. Difficulties persist in qualifying certain species as sedentary or not, according to UNCLOS Art. $77^{3}$. Actually, certain species which can be qualified a sedentary or non-sedentary, living slightly above the seabed of the joint management area, fall within the scope of the SIOFA (including certain fish, molluscs and crustaceans).

In 2018, SIOFA has established five provisionally designated benthic protected areas (Fig.3) whose Walters Shoal is part of, that are taken from the initial 13 SIODFA BPAs, and is in the process of mapping areas where VME encounters are known to occur on the basis of bottom fishery impact assessments. The binding measure CMM 2019/01 prohibits bottom

\footnotetext{
${ }^{2}$ At the SIOFA, the terms 'bottom fishing' mean fishing using any gear type likely to come in contact with the seafloor or benthic organisms during the normal course of operations. It includes bottom trawl, mid-water trawl, bottom line and traps or pots.

${ }^{3}$ Article 77 of the UNCLOS defines sedentary species as those "which, at the harvestable stage, either are immobile on or under the seabed or are unable to move except in constant physical contact with the seabed or subsoil"
} 
fishing (with the exclusion of line and trap methods) in the BPAs, and stipulates that scientific observers must be onboard while fishing inside those areas with any other gear. It is therefore with a regional Law of benthic fisheries (under SIOFA) that one must deal with from now on.

\section{3- Towards seamounts as conservation units}

The international law in the high seas is dominated by poorly coordinated sectoral regimes (Galletti, 2015). The seamounts are just an illustration of this analysis. The regulation of offshore biological and mineral resources are distinct and separate and the two related economic sectors have been, until now, rather reluctant to any holistic approach regarding seamounts. Recent progress can be acknowledged in the Indian Ocean through the SIOFA management measures, and through the regional environmental management plans that are being developed under the ISA Mining Code, as noted before. Different perspectives are noted between what refers to seamount species on one hand, and to fragile habitats on the other hand. This distinction indicates why conservation units are needed for seamounts.

\subsection{The issue of seamount species}

The first concern is about the species that live and are incidentally caught at the seamounts, and the environmental rights of the species (status and listing). The question is whether they are legally protected and how. Through the Convention on Migratory Species and its provision for sub-agreements, States along their coasts, in their EEZs and beyond, can decide to protect seamounts and their associated species. In the Convention on International Trade in Endangered Species of Wild Fauna and Flora (CITES) the number of marine species that are protected or trade-managed is minimal. The key taxa of concern on seamounts are the sponges and corals. While the Gorgoniacea Corallium spp (red/pink corals) are listed in Appendix III, the other coral species, all present in the SWIO, such as the Antipatharia (black corals), Scleractinia (stony corals), Tubiporidae (organ pipe corals), and Sylasteridae (lace 
corals), are listed in Appendix II, which includes species of concern. None of the coral species are listed in the Appendix I of the CITES (most endangered species in CITES lists). The status of seamount-associated species has been overlooked so far and needs to be addressed by the CITES.

The International IUCN Red List of Threatened Species (www.iucnredlist.org) is another assessment tool, however with no legal value. It helps identifying those species in need of recovery actions. Concerning the SWIO, among 3826 species reported, 335 are deep benthic marine species and 833 are oceanic species. Deep-sea bony fish species, such as orange roughy, alfonsinos, bioluminescent lanternfishes which can occur deeper than $1000 \mathrm{~m}$, as well as deep-water sharks, enter the Red List. Many deep-sea fish assessments are considered as "Data Deficient". We also note the introduction in the Red List of the first deep-sea hydrothermal vent mollusc, Chrysomallon squamiferum, or the Scaly-foot Snail (Endangered), met on three locations restricted to hydrothermal vents on deep-ocean ridges in the Indian Ocean, at depths of up to 2,900 m (Sigwart et al, 2019). In addition, most seamount- associated species have a commercial status in fisheries: target, by-catch, or discard.

\subsection{The issue of seamount habitats and ecosystems}

The VME concept introduced by FAO in 2009 refers to a functional or structural traits based on various criteria (rarity, functional significance, fragility, life history traits of component species, structural complexity of the site). Therefore, RFMOs and fishing states have taken initiatives to mitigate significant adverse impacts of fishing on VMEs. In 2019, SIOFA has adopted a list of VME taxa for its area of competence, a first step towards establishing binding management procedures regarding VMEs. This list includes nine orders among the Cnidaria, two classes of Porifera, Ascidiacea, Bryozoans, Brachiopoda, Pterobranchia, Serpulidae, Xenophyophora, Bathylasmatidae, Stalked crinoids, Euryalida and 
Cidaroida. The next step is the application of a common VME encounter protocol when VME thresholds are reached. Presently, there are no agreed and unified threshold levels and moveon rules (requiring vessels to stop fishing in the impacted area) at the SIOFA, as each flag is applying its own criteria or those existing at the Commission for the Conservation of Antarctic Marine Living Resources (CCAMLR). Moreover, units used to quantify the VME taxa caught are not homogeneous, either expressed in $\mathrm{kg}$ or liters. There are also disagreements between flag states at SIOFA on setting up a regulation concerning all gears. The SIOFA Scientific Committee (SC) has recommended that, whatever the gear, bottom fishing should be considered as degrading the scientific and biodiversity value of the area, although bottom fishing gears have different levels of impact. Trawl fishing is closed in the interim BPAs, however detailed observations on the impact of non-trawl gears is lacking for several flag states. All VME data should be reported, not just triggers of VME encounters. Such obligation does not exist yet at SIOFA.

High-resolution bathymetric mapping and habitat delineation are essential to define science-based regulations. Several flag states have conducted such studies in the framework of bottom fishery impact assessments. Following Last et al (2010) the SIOFA area was classified into six bathomes ("ecologically meaningful depth ranges within fishable depths") defining preferred habitats for various groups of taxa based on depth. In the absence of detailed biological information on the communities present at seamounts, and as a precautionary approach, depth ranges could be used as surrogates for VME fauna.

\subsection{How seamounts conservation units might be established?}

For such an objective, a legal existence should be given to seamounts, so that specific regulations can be attached to them. The first approach is to progress from merely temporary legal rules towards a definitive and long-term regulation. Interim measures have the advantage of provisional law, allowing some protection while the States and Parties continue 
to negotiate a more satisfactory agreement (Galletti, 2004). However, interim measures can be challenged at each annual meeting by the most uncooperative States or Parties. Business-asusual scenarios can sometimes be preferred by some flag states. The role of the scientific advice here is key to propose science-based rules, aiming at conservation of fragile ecosystems; this is what the SIOFA SC is committed to, as indicated earlier.

The second approach is to establish Marine Protected Areas (MPAs) around seamounts of particular scientific and bioregional interest. Such a management measure can be implemented by a single State, when a seamount is present in its waters, or by RFMOs for seamounts located in the ABNJ. However, the latter is quite unusual. It was achieved by the Oslo-Paris (OSPAR) Commission with OSPAR MPAs in the North-East Atlantic. In the SWIO, the five provisional BPAs adopted by SIOFA might end up as a permanent measure. Such process initiated by SIOFA goes over the traditional role of RFMOs to assess stocks and manage fisheries. The BPAs represent one type of marine spatial protection, which, though partial, introduces new measures restricting access to the fishing fleets as limiting catches or footprint, imposing a move-on rule to another site in case of encounter with a VME, obligation to undertake bottom fishing impact assessments and to submit a management plan. This set of measures forms the embryo of an MPA regulation. However the transfer of such seamount status into a fully protected space is not achieved so far, while this could be set as a medium-term objective for the most sensitive sites. The current situation is that there are many gaps in the existing framework for the protection of biodiversity in ABNJ, as reviewed by Wright et al (2018), including the absence of a global framework to establish any type of MPAs in ABNJ.

A comprehensive protection of fragile ecosystems would be reached by including regulation on deep-sea mining to the fishing regulation, i.e. banning extractive activities and declaring no-take areas for the concerned seamounts. A full protection status in the ABNJ 
would in theory become possible thanks to the reform initiated under UNCLOS. Since 2006, discussions convened under the United Nations General Assembly aim to elaborate an "international legally binding instrument" (ILBI) for the conservation and sustainable use of marine biodiversity in areas beyond national jurisdiction (BBNJ process). The spirit of this instrument is presently based on four elements. Two of them, area-based management tools (ABMTs) including MPAs, and environmental impact assessments (EIAs) are of particular relevance for seamounts in ABNJ. The ILBI is expected to include provisions to establish integral ABNJ MPAs, which constitute a drastic evolution in both the Law of the Sea and the form of ocean governance. It would enable new MPAs to incorporate all biotic and abiotic components, unlike most of marine sanctuaries that are limited to certain species, such as those banning whaling and reducing threats to whales (Sorby, 2018), benthic protected areas (noted earlier) or pelagic MPAs. This future legal instrument relevant to the UNCLOS opens up unprecedented possibilities for bilateral or regional cooperation in identification, design and management of sites from high-resolution mapping. Yet, these possibilities will remain pure theory if not connected to documented and scientifically supported cases of seamounts, alongside diplomatic actions and financial resources allocated to this aim. Nevertheless, a number of issues still need to be resolved within the ILBI with relevance to seamounts, inter alia: a more clear definition of the sedentary species (still open to controversy) especially the fact that such status is disconnected from the concept of biodiversity, the possibility to develop area-based measures (ABMTs) in the water column in support of environmental protection of the shelf (or seamount) biodiversity, and the articulation of the new regulation with existing regional and global organizations (Mossop, 2017). In the following section, we shall connect these reflections with a practical case, the Walters Shoal, and discuss whether it could be a candidate for a fully protected seamount.

\section{4- The Walters Shoal: an ABNJ seamount case-study in the SWIO}


The Walters shoal is one emblematic seamount among the other isolated sites where issues of maintaining a natural and shared heritage arise. The environmental characteristics and isolation of this site are reviewed to discuss the value of classifying it as an ILBI-type integral MPA.

\subsection{Environmental setting}

The Walters Shoal $\left(43^{\circ} 54^{\prime} \mathrm{E} / 33^{\circ} 12^{\prime} \mathrm{S}\right)$ is an isolated seamount located on the Madagascar Ridge, $855 \mathrm{~km}$ South of Madagascar, $1300 \mathrm{~km}$ East of the South African coast, $1760 \mathrm{~km}$ from Reunion Island (France), $1600 \mathrm{~km}$ from Crozet (France), and $1600 \mathrm{~km}$ from Prince Edwards Islands (South Africa). The Madagascar Ridge extends southwards from the Madagascar landmass. No obvious magnetic anomalies, which would have supported an oceanic origin, have been found along this plateau. Some models of the Indian Ocean basin evolution consider that the Madagascar Ridge to be partly continental (Reeves, 2014). These considerations on geological continuity of the seabed with the adjacent landmasses have considerable implications in the allocation of the "Extended Continental Shelf" to coastal States under the UNCLOS.

Discovered in 1962 by the South African vessel Natal, the Walters Shoal is one of the most emblematic and atypical seamount in the SWIO, located in the ABNJ at the confluence of the Sub-tropical and the Sub-Antarctic waters. The seafloor mapping performed during the MD208-Walters Shoal cruise in 2017 (DOI: 10.17600/17002700) reveals a complex submarine morphology which is different from other seamounts previously described in the region (Courgeon et al., 2016, 2017) (Fig. 4). The base of the edifice lies on the Madagascar Ridge at about $600 \mathrm{~m}$ depth and the flat top is located at around an average depth of $18 \mathrm{~m}$. Previous investigation showed a caldera-like shape of the summit, with depth of the order $\sim 50 \mathrm{~m}$ in the middle part of the peak ( $R V$ Marion Dufresne cruises in 1973 and 1976, unpublished data). Rocks collected at the vicinity and along the flanks of the seamount are 
diverse. Cold-water carbonates such as algal and rhodolithes (coralline algae) are abundant especially on top of the seamount but also on submerged terraces. Volcanic glass and basalt fragments collected in some samples confirm that the seamount has formed by volcanic extrusion on the seafloor.

The Walters Shoal benthic fauna has been subject to dedicated cruises. In 1964, the $R V$ 'Anton Bruun' discovered several news species of marine invertebrates such as the crinoid Comanthus wahlbergi tenuibrachia Clark, 1972 and crustaceans Jaeropsis waltervadi Kensley, 1975 and Alpheus waltervadi Kensley, 1969. In 1988, the Soviet Oceanographic Vessel 'Vityaz' carried out the most extensive exploration of this seamount to date, both in the summit area and on the slopes as deep as 2050 meters. It provided the most comprehensive list of fish species including eight endemic species (Collette and Parin 1991; Parin et al. 1993). Despite these surveys, the annelid Synelmis britayevi Salazar-Vallejo, 2003 and the lobster Palinurus barbarae Groeneveld, Griffiths \& Van Dalsen, 2006 were only recently discovered as new for science. The most recent inventory of the benthic fauna and flora was performed by the Museum National d'Histoire Naturelle (MNHN, France) in the context of the Tropical Deep Sea Benthos program (https://expeditions.mnhn.fr/program/tropicaldeep-seabenthos) during the MD208 cruise. So far, the total number of species identified there is around 250 including a majority of small invertebrates (mollusks, crustaceans), 20 fish species and more than 60 species of algae. New species of Asterids from this cruise have been recently published (Mah, 2018) suggesting that the ongoing taxonomic studies could reveal new endemic species and benthic assemblages.

Nevertheless, in comparison to tropical seamounts, the Walters Shoal fauna (and flora) remains indeed unquestionably poor, mostly composed of small, endemic and new species. The ecological facies of the Walters Shoal with a coralligenous top (Fig. 5) and the great diversity of habitats along the slopes is a truly remarkable environment. At its $4^{\text {th }}$ session, the 
SIOFA SC has recognized this seamount as an area of bioregional significance (SIOFA, 2019). The physical and biological setting of the Walters Shoal render this site a unique "biogeographic feature" in the SWIO with should be preserved from both mineral extractive and fishing activities.

\subsection{Regional connectivity and local retention}

The connectivity within the SWIO has been investigated by Lagrangian modelling where larvae released at different sites act only as passive drifters (Crochelet et al., this issue). This study concludes that Walters Shoal is weakly connected to the seamounts, plateaus and coastal ecosystems located north of $26^{\circ} \mathrm{S}$, or to the Mozambique Channel and the East African coast, even after 4 months of drift $(<0.1 \%$ of 'artificial' larvae released at sites and reaching destination). By contrast, the model represents a high local retention at Walters Shoal, which is ranked first (12\% of released larvae staying on site) among all seamounts of the SWIO region (Crochelet et al., this issue).

In line with connectivity, the matter of seamount-related endemism (at the scale of a chain of seamounts, between seamounts separated by oceanic basins and with inshore areas) has become a major research area in the context of conservation of fragile and iconic species. For some authors seamounts harbor isolated benthic species, promoting endemism (Richer de Forges et al., 2000; Gjerde \& Breide, 2003). Nevertheless, this is not a compelling evidence everywhere as contrasted situations have been reported (Gofas, 2000; Dijkstra \& Gofas, 2004) and studies including adjacent continental margin fauna showed evidences of faunal exchanges (Samadi et al., 2006; Hall-Spencer et al., 2007; Thoma et al., 2009). Endemism is deeply related to life-history traits, also to the ocean circulation pattern, however the paradigm that endemism is particular high at seamounts is challenged (Rowden et al, 2010). In the case of the Walters Shoal, we can note a good agreement between the high local retention rate 
502

estimated by the Lagrangian model and the relatively high number of endemic species being discovered at that seamount.

\subsection{Discussion on a possible integral MPA for the Walters Shoal}

The scientific knowledge acquired on Walters Shoal's ecosystem has led to its recognition as a seamount of bioregional importance against a set of criteria, including VMEs (SIOFA, 2019). The Walters Shoal is located in the ABNJ but this status may change alongside a submission made by Madagascar to the CLCS defining the outer limits of its continental shelf.

\subsubsection{Possible perimeters for a Walters Shoal's integral MPA}

The delineation of MPA perimeters is generally based on scientific elements, biological or geological. However, the rules of the International Law of the Sea are of key importance especially for the legal layout, the delineation methodology, including the rights of the nearest States concerned by an issue of continental shelf extension (France, Madagascar, Mozambique and South Africa for the SWIO). In many instances, the knowledge of biological properties of a site is not considered whilst boundaries are set quasi exclusively on the basis of the geomorphological profile. Under UNCLOS, as well as in the customary international law (for States that have not ratified UNCLOS), the determination of the legal extent of conservation units requires (i) knowledge of the geophysical characteristics of the seabed and subsoil; (ii) the use of "formulas" based on the position of the foot of continental slope or the sediment thickness; and (iii) the selection of delineation constraints (inter alia 350 $\mathrm{M}$ from coastline, or $100 \mathrm{M}$ from the $2500 \mathrm{~m}$ isobath). These considerations lead us to conduct an exercise of perimeter delineation for a Walters Shoal's MPA where both the benthic habitat and the superjacent water column would be regulated (as this seamount is also a landmark for large marine mammals, as reported in the introduction). There is sufficient scientific information produced by the MD208 cruise to claim that depth ranges larger than 
the current SIOFA "Walters Shoal BPA" have ecological peculiarities. The 200-500 m fauna does not share any species with the upper plateau while the $600-1000 \mathrm{~m}$ and $1500-2000 \mathrm{~m}$ sections are different from each other and have no analog in the upper layers (Bouchet and Corbari, comm. pers). A conservation effort directed on a single stratum (like the SIOFA BPA) would not be sufficient here. Four possible perimeters around the Walters Shoal ranked by decreasing size (Fig. 6) are proposed and briefly discussed:

- An area demarcated by the $2500 \mathrm{~m}$ isobath $\left(309700 \mathrm{~km}^{2}\right)$ because this specific depth contour could become a legal key element for the delineation between a Madagascar's extended continental shelf and an ABNJ Walters Shoal MPA. This isobath also represents a wider geomorphologic entity where the Walters Shoal is located;

- An area demarcated by the $2000 \mathrm{~m}$ isobath $\left(165200 \mathrm{~km}^{2}\right)$ with its northern boundary being tangential to the legal theoretical $350 \mathrm{M}$ limit. Such depth includes ecological features that are of insular $(0-1500 \mathrm{~m})$ and deep marine $(>1500 \mathrm{~m})$ nature. It is also useful to include depth ranges that can be compared with other sites to understand the effects of connectivity and benthic settlement. For instance, the presence of the bonus Thalassocyon gastropod was reported by Bouchet (comm. pers) at $2000 \mathrm{~m}$ on the slopes of Walters Shoal, while this species was described and known until now only in South Africa.

- An area centered in the Walters Shoal and demarcated by the $1000 \mathrm{~m}$ isobath (102000 $\mathrm{km}^{2}$ ), also including four smaller seamounts located in the close vicinity (west and southwest) of the Madagascar Ridge. This area matches the patch of higher density of retention of passive larvae (Crochelet et al, this issue) which could suggest a strong homogeneity in fauna between the Walters Shoal and these neighboring seamounts.

- The Walters Shoal summit $\left(33^{\circ} 12^{\prime} \mathrm{S} / 43^{\circ} 54^{\prime} \mathrm{E}\right)$ and its slope, a minimal conservation area of $3100 \mathrm{~km}^{2}$ (for comparison, the SIOFA Walters Shoal BPA has an area of 3443 
$\mathrm{km}^{2}$ ). This perimeter can be considered quite small, but in terms of ecological facies, an isolated seamount summit with coralligenous habitat is a remarkable environment. For these reasons, the top of Walters Shoal remains a unique biogeographic entity (FFEM, 2019)

These four areas represent respectively 9.6, 5.1, 3.2 and 0.1 times the size of the five existing interim BPAs adopted by the SIOFA. The reasoning based on isobaths and depth ranges to define conservation units is supported by the bathome surrogacy of VME taxa, as previously mentioned (see section 3.2) after Last et al (2010).

\subsubsection{The Walters Shoal in the perspective of an extended Madagascar's continental shelf}

Madagascar has made a submission in April 2011. The new seabed under its jurisdiction would then reach a distance of almost 900 M south of the country's landmass (Fig. 7). Whether or not the Walters Shoal will eventually be part of the Madagascar's continental shelf will depend on the scientific and technical data supplied by Madagascar in support of its claim on geological continuity, and the scientific acceptance by the CLCS. The fate of Walters Shoal is therefore uncertain, as it may either remain in the ABNJ or fall under Madagascar sovereign rights. Whatever the outcome, it is essential that a full conservation of this site is warranted. The search for an ambitious and coherent perimeter for a Walters Shoal MPA will then have to go through a zoning exercise, therefore through bilateral or multilateral cooperation agreements to manage, enhance, and finance an area where biological monitoring could be accepted as a new priority.

\section{5- Proposed guidelines in a Nairobi Convention framework}

The access to seamounts of regional or global importance in the SWIO and to the protection of their ecosystems and resources were among the concerns raised to the attention of the Nairobi Convention. Its area of competence covers the EEZs of 10 States (Comoros, France, Kenya, Madagascar, Mauritius, Mozambique, Seychelles, Somalia, Tanzania and the 
Republic of South Africa). During the PRECop 9 (Galletti et al., 2018) and COP 9 of the Nairobi Convention in August 2018. The goal was to arouse the interest of the Contracting States for public decisions addressing shared issues, including the deep-environment, to ensure a sustainable use of natural resources, in line with UN SDG14.

It is worth recalling the principles leading to consider a maritime governance of seamounts ecosystems within the amended Nairobi Convention for the Protection, Management and Development of the Marine and Coastal Environment of the Western Indian Ocean. Through one of its protocols, related to Integrated Coastal Zone Management (under negotiation), this would allow inter alia that sites localized between EEZs, or even between EEZs and ABNJ (therefore outside the current area of competence of the amended Nairobi Convention) might be treated together under the criteria of ecological (and to some extent, economical) connectivity. In order to ensure the sustainability of the coastal and offshore fisheries in the region (Popova et al., 2019), the biodiversity of seamounts, even those in the ABNJ, should ideally be protected. For those seamounts, an extended mandate of the Nairobi Convention could be conceivable since the governance of the Nairobi Convention is evolving. For instance, the decision CP9/7 (2018 - UNEP/EAF/CP.9/3) explicitly requests Contracting Parties, and other partners, to support projects for the conservation and sustainable exploitation of seamount and hydrothermal vent ecosystems of the SWIO in ABNJ and to collaborate in the management of activities in their adjacent waters with the IUCN.

The Nairobi Convention is promoting an agreement on a Regional ocean governance strategy for the WIO region to guide States in their development agenda and to develop a partnership approach for implementing SDG14. Seamounts must be part of this strategy. The framework of the preparatory meetings for the Nairobi Convention biennial meetings (CoP) and the Convention work plan 2018-2022, provide a new adequate framework for the acquisition of multidisciplinary knowledge that is essential in the multilateral public decision- 
making process relevant to seamounts protection. However we recognize the long road between the science-based evidence and the adoption of exclusionary decisions, as in the case of MPAs.

The Nairobi Convention work plan should then:

1. Promote marine spatial planning studies in order to compile an inventory of the existing and planned at-sea activities in the whole SWIO region, in both areas under national jurisdiction and international waters;

2. Encourage historical data rescue activities on seamounts of the SWIO in order to set up a knowledge base on the marine natural heritage, its potential and its vulnerability; 3. Develop multidisciplinary capacities in the administration of the riparian states in order to design harmonized management plans dedicated to seamounts conservation in EEZ and their adjacent waters where distant and/or connected seamounts are located;

4. Examine the issue of extending its geographical competence beyond national jurisdiction as a consequence of different types of connectivity (economic, ecological...) between seamounts located in international waters and coastal zones, which will require new type of partnership with non-member States;

5. Draw the attention of the States on the situation of seamounts included on the legal continental shelf of a coastal State whereby pelagic resources fall within the jurisdiction of RFMOs while living benthic, demersal and mineral resources come under the jurisdiction of the coastal state that exercise certain rights on the continental shelf. Therefore, it is proposed that the Nairobi Convention facilitates the implementation of harmonized conservation/exploitation policies of those entities;

6. Account for new measures from RFMOs, in particular the five SIOFA seamount BPAs in ABNJ waters (Walters Shoal, Coral, Middle of What, Atlantis Bank, Fools 
Flat), with ban of bottom trawl fishing and mandatory boarding of observers for all other gears, pending a final management plan by SIOFA in 2019;

7. Support the States to engage any form of partial or total network protection of areas of scientific and bioregional importance that is partially documented by the Large Marine Ecosystems (LME), the EBSA process, or the oceanographic cruises, but which presently remains without any legal protection;

8. Capitalize on opportunities provided in the ILBI to enable convergence of the Indian Ocean States on 5 themes: i) spatial management and MPAs in international waters; ii) marine technology transfer; iii) sharing advantages of the genetic diversity; iv) combating IUU fishing and v) environmental impact assessments.

These guidelines are rather generic in terms of regional management. However, due to the focus made in this paper on the governance in the SWIO, they are clearly directed to the Nairobi Convention as a contribution to new objectives being reshaped in the perspective of an extended mandate of this organisation. If they were acknowledged and implemented by the sole members States of the Nairobi Convention, these guidelines would represent a significant progress from the present situation.

\section{6- Conclusion}

In a blue economy perspective, seamounts are anything but anecdotal for the wealth of Indian Ocean nations. Several of them form refuges with remarkable species richness. Through connectivity by the ocean circulation, overfishing and loss of biodiversity on seamounts and shoals can negatively affect fisheries, livelihoods and ecosystem services along the coastlines. For a while, the seamounts have been utilized as a source of profit, often in an unsustainable manner. Therefore, more stringent measures need to be established around those particular spaces and towards the design of marine protected areas or any other kind of conservation unit. 
Although establishing an MPA around an isolated seamount would be a significant step

652

653

654

655

656

657

658

659

660

661

662

663

664

665

666

667

668

669

670

671

672

673

674

forward, this might not be sufficient to ensure an efficient protection of sensitive ecosystems and sustain their ecological functions. It is therefore highly desirable to identify the seamounts to be protected and create a legal networks of seamounts-MPAs by connecting them through corridors (Galletti, 2014). Seamounts networks should be embedded into the legal zoning of area-based management tools (ABMTs), including MPAs in ABNJ that the ILBI would render possible.

We have attempted to document the possible establishment of a fully protected MPA centered on the Walters Shoal, with different possible perimeters, on the basis of scientific evidence of its biological uniqueness and possible new legal framework that could be implemented under UNCLOS and in a regional seas organization under UNEP, the Nairobi Convention. This can be viewed as an anticipation exercise as the legal and international framework in the $\mathrm{ABNJ}$ is still lacking, more exactly not yet available (at the time of writing) as 2020 should be the year when ILBI is completed. However we are convinced that our arguments, in complement to other ongoing studies and discussions, can contribute to a gradual evolution towards more conservation units established in the medium term in the waters under national jurisdiction as well in ABNJ of the SWIO.

\section{Disclaimer}

This article is a research paper. The views expressed by the authors do not necessarily reflect those of their affiliated institutions. The designations employed do not imply the expression of any opinion whatsoever on the part of affiliated institutions concerning the legal status of any country, territory, or area or of its authorities, or concerning the delimitation of its frontiers or boundaries. The presentation of material prejudges no support for claiming States.

\section{Acknowledgements}


675 The authors wish to thank the officers and crew of the $R / V$ Marion Dufresne II. The cruise 676 MD208 was a part of the FFEM-SWIO project on Areas Beyond National Jurisdiction 677 (ABNJ) of the southwestern Indian Ocean, funded by the Fonds Français pour 678 l'Environnement Mondial (FFEM) and coordinated by the IUCN. The MD208 cruise was 679 facilitated by the Institut Polaire IPEV, France. We are also grateful to the two reviewers for 680 their critical comments and useful suggestions that allowed us to revisit and consolidate some 681 points of the paper and improve the quality of the initial manuscript.

682 


\section{References}

Best, P.B., Findlay, K.P., Sekiguchi, K., Peddemors, V.M., Rakotonirina, B., Rossouw, A., Gove, D. (1998). Winter distribution and possible migration routes of humpback whales Megaptera novaeangliae in the southwest Indian Ocean. Mar. Ecol. Prog. Ser. 162: 287299

Buhl-Mortensen, L., Vanreusel, A., Gooday, A.J., Levin, L.A., Priede, I.G., Buhl-Mortensen, P., Gheerardyn, H., King, N.J., Raes, M. (2010). Biological structures as a source of habitat heterogeneity and biodiversity on the deep ocean margins. Marine Ecology 31: 21-50.

Cerchio, S., Trudelle, L., Zerbini, A.N., Charrassin, J.B, Geyer, Y., Mayer, F-X., Andrianarivelo, N., Jung, J-L., Adam, O., Rosenbaum, H.V. (2016). Satellite telemetry of humpback whales off Madagascar reveals insights on breeding behavior and long-range movements within the southwest Indian Ocean. Mar. Ecol. Prog. Ser. 562: 193-209.

Chapman, D.C. and Haidvogel, D.B. (1992). Formation of Taylor Caps over a tall isolated seamount in a stratified ocean. Geophysical and Astrophysical Fluid Dynamics, 64: 3165.

Clark, A.M. (1972). Some crinoids from the Indian Ocean. Bulletin of the British Museum (Natural History), 24(2): 73-156.

Clark, M.R. (2009). Deep-sea seamount fisheries: a review of global status and future prospects. Latin American Journal of Aquatic Research 37(3). 501-512.

Clark, M.R., Vinnichenko, V.I., Gordon, J.D.M., Beck-Bulat, G.Z., Kukharev, N.N, Kakora, A.F. (2007). Large-scale distant-water trawl fisheries on seamounts. In Pitcher, T.J., Morato, T., Hart, P.J.B., Clark, M.R., Haggan, N., Santos, R.S. (Eds.), Seamounts: Ecology, Fisheries \& Conservation 12. Blackw ell Publishing, Oxford, U.K, 361-399.

Clark, M.R., Rowden, A.A, Schlacher, T., Williams, A., Consalvey, M., Stocks, K.I., Rogers, A.D., O’Hara, T.D., White, M., Shank, T.M. and Hall-Spencer, J.M. (2010). The ecology of seamounts: Structure, function and human impacts. Annual Review of Marine Science, 2: $253-278$

Clark, M.R., Watling, L., Rowden, A.A., Guinotte, J.M., Smith, C.R. (2011). A global seamount classification to aid the scientific design of marine area protected networks. 
Ocean \& Coastal Management, 54:19-36. https://doi.org/10.1016/ j.ocecoaman.2010.10.006.

Clark, M.R., Schlacher, T.A., Rowden, A.A., Stocks, K.I., Consalvey, M. (2012). Science priorities for seamounts: research links to conservation and management. PLoS One 7, e29232. https://doi.org/10.1371/journal.pone.0029232

Clark, M.R., Bowden, D.A., Rowden, A.A., Stewart, R. (2019). Little evidence of benthic community resilience to bottom trawling on seamounts after 15 years. Frontiers in Marine Science, 6, 1-16. doi:10.3389/fmars.2019.00063

Collette, B.B., Parin, N.V. (1991) Shallow-water fishes of Walters Shoals, Madagascar Ridge. Bull. Mar. Sci.48: 1-22.

Courgeon, S., Jorry, S.J., Camoin, G.F., BouDagher-Fadel, M.K., Jouet, G., Révillon, S., Bachèlery, P., Pelleter, E., Borgomano, J., Poli, E., Droxler, A.W. (2016). Growth and demise of Cenozoic isolated carbonate platforms: New insights from the Mozambique Channel seamounts (SW Indian Ocean). Mar. Geol. 380: 90-105.

Courgeon S., Jorry S.J., Jouet G., Camoin G.F., Boudagher-Fadel M.K., Bachelery P., Caline B., Boichard R., Revillon S., Thomas Y., Thereau E., Guerin C. (2017). Impact of tectonic and volcanism on the Neogene evolution of isolated carbonate platforms (SW Indian Ocean). Sedimentary Geology, 355, 114-131.

Crochelet, E., Barrier, N., Andrello, M., Marsac, F., Spadone, A., Lett, C. (this issue). Connectivity between seamounts and coastal ecosystems in the South West Indian Ocean. Deep-Sea Res II.

Dijkstra, H., and Gofas, S. (2004). Penctinoidea Bivalvia: Propeamussiidae and Pectinidae from some northeastern Atlantic seamounts. Sarsia: North Atlantic Marine Science, 89: $33-78$.

Dulau, V., Pinet, P., Geyer, I., Fayan, J., Mongin, P., Cottarel, G., Zerbini, A., Cerchio, S. (2017). Continuous movement behavior of humpback whales during the breeding season in the Southwest Indian Ocean: on the road again. Movement Ecology, 5:11

Ebert, D.A. (2013). Deep-sea Cartilaginous Fishes of the Indian Ocean. Volume 1. Sharks. FAO species catalogue for fishery purposes. No. 8, Vol. 1. Rome, FAO., 256 p. 
Ebert, D.A. (2014). Deep-sea Cartilaginous Fishes of the Indian Ocean. Volume 2. Batoids and Chimaeras. FAO Species Catalogue for Fishery Purposes. No. 8, Vol. 2. Rome, FAO., 138 p.

FAO (2009). International Guidelines for the Management of Deep-Sea Fisheries in the High Seas, FAO, Roma, 73p

FAO (2017). FAO global fishery and aquaculture production statistics v.2017.1.0.

FFEM (2019). De la science à la gouvernance de la haute mer - Exploration et gestion des monts sous-marins du sud-ouest de l'océan Indien. Publication FFEM, Paris.

Galletti, F. (2004). Notion et pratiques de «L'arrangement provisoire» prévu aux articles $74 \S 3$ et $83 \S 3$ de la Convention sur le droit de la mer. Une contribution marginale au droit de la délimitation maritime? ". Annuaire International du Droit de la Mer (ADM), Tome IX, INDEMER Institut Économique du Droit de la Mer de Monaco, Ed. Pedone, 2005: 115-142.

Galletti, F. (2014). La protection juridique des réseaux écologiques marins. Compétences et implications du droit de la mer contemporain. Sobrino Heredia J.M. (ed.), The contribution of the United Nations Conference of the Law of the See to good governance of the oceans and seas, (Vol. 2), Editoriale Scientifica, Napoli: 765-791.

Galletti, F. (2015). Transformations in international Law of the Sea : Governance of the «Space» or «Resources» ?. Monaco A. et Prouzet P. (eds.), Governance of Seas and Oceans, Iste Editions Ltd \&, London: 1-37.

Galletti, F., Marsac, F., Ternon, J-F. (2018). Governance of the South West Indian Ocean Seamounts, A contribution to FARI (Forum for Heads of Academic and Research Institutions), Science to Policy meeting before the 9Th COP of the Nairobi Convention, 10 July 2018, Durban, South Africa, 4 p. https://wedocs.unep.org/bitstream/handle/ 20.500.11822/25702/seamount_governance.pdf?sequence=1\&amp;isAllowed=y

Garcia, S.M., Cohen, H., Freestone, D., Martinez, C., Oral, N., Rogers, A., Verlaan, P.A. and Vousden, D. (2013). An Ecosystem Approach to Management of Seamounts in the Southern Indian Ocean. Volume 4 - A Road Map towards sustainable use and conservation of biodiversity in the Southern Indian Ocean. Gland, Switzerland: IUCN. 32 + iv pp. 
Georgeson, L., Rigby, C.L., Emery, T.J., Nicol, S.J., Fuller, M., Hartog, J., Hobday, A.J., Simpfendorfer, C.A. (2019). Ecological risk assessment for the effects of bottom fishing gears on deepwater chondrichthyans in high seas areas of the Southern Indian and South Pacific oceans. First Meeting of the Stock and Ecological Risk Assessment Working Group, SIOFA, 20-22 March 2019, Yokohama, Japan, 25 p.

Gjerde, K.M., Breide, C. (2003). Towards a strategy for high seas marine protected areas. Proceedings of the IUCN, WCPA, and WWF Experts' Workshop on High Seas Marine Protected Areas, 15 to 17 January 2003,Malga, Spain, IUCN, Gland, Switzerland.

Gofas, S. (2000) Four species of the family Fasciolariida (Gastropoda) from the North Atlantic seamounts. Journal of Conchology, 37, 7-16.

Groeneveld, J.C., Griffiths, C.L., van Dalsen A.P. (2006). A new species of spiny lobster, Palinurus barbarae (Decapoda, Palinuridae) from Walters Shoals on the Madagascar Ridge. Crustaceana, 79(7): 821-833.

Hall-Spencer, J., Rogers, A., Davies, J., Foggo, A. (2007). Deep-sea coral distribution on seamounts, oceanic islands, and continental slopes in the Northeast Atlantic. Bulletin of Marine Science 81: 135-146.

IHO (2008). Standardization of undersea feature names: Guidelines proposal form terminology, 4th edition. International Hydrographic Organization and International Oceanographic Commission, International Hydrographic Bureau, Monaco, 32 pp

ISA (2007). Polymetallic sulphides and cobalt-rich ferromanganese crusts deposits: establishment of environmental baselines and an associated monitoring programme during exploration. In: Proceedings of the international seabed authority's workshop, September 2004; 2007 [chapter 13]. p. 295e308. http://www.isa.org.jm/en/ documents/publications.

ISA (2019). Report on the status of the contracts for exploration, Twenty-fifth session, Legal and Technical Commission session, part I Kingston, 4-15 March 2019, 7 p.

Johnston, D.W, McDonald, M., Polovina, J., Domokos, R., Wiggins, S., Hildebrand, J. (2008). Temporal Patterns in the Acoustic Signals of Beaked Whales at Cross Seamount. Biology Letters 4 (2): 208-11. https://doi.org/10.1098/rsbl.2007.0614.

Kensley, B. (1969) Decapod Crustacea from the south-west Indian Ocean. Annals of the South African Museum 52: 149-181. 
Kensley B. (1975). Five species of Jaeropsis from the southern Indian Ocean (Crustacea, Isopoda, Asellota). Annals of the South African Museum, 67(10): 367-380.

Kitchingman, A., Sherman, L., Morato, T, Pauly, D. (2007). How many seamounts are there and where are they located? In Pitcher, T.J., Morato, T., Hart, P.J.B., Clark, M.R., Haggan, N., Santos, R.S. (Eds.), Seamounts: Ecology, Fisheries \& Conservation 12. Blackwell Publishing, Oxford, U.K, 26-40.

Last, PR, Lyne, VD, Williams, A, Davies, CR, Butler, AJ, Yearsley, GK (2010), A hierarchical framework for classifying seabed biodiversity with application to planning and managing Australia's marine biological resources', Biol Cons, 143(7): 1675-1686.

Lodge, M., Johnson, D., Le Gurun, G., Wengler, M., Weaver, P., Gunn, V. (2014). Seabed mining: International Seabed Authority environmental management plan for the ClarionClipperton Zone. A partnership approach. Mar. Policy, 49: 66-72

Lucena-Fredou, F., Kell, L., Fredou, T., Gaertner, D., Potier, M., Bach, P., Travassos, P., Hazin, F., Ménard, F. (2017). Vulnerability of teleosts caught by the pelagic tuna longline fleets in South Atlantic and Western Indian Oceans. Deep-Sea Research II, 140: 230-241

Mah, C. L. (2018). New genera, species and occurrence records of Goniasteridae (Asteroidea; Echinodermata) from the Indian Ocean. Zootaxa, 4539(1), 1-116.

Morato, T., Clark, M.R. (2007). Seamount fishes: ecology and life histories. In Pitcher, T.J., Morato, T., Hart, P.J.B., Clark, M.R., Haggan, N., Santos, R.S. (Eds.), Seamounts: Ecology, Fisheries \& Conservation 12. Blackwell Publishing, Oxford, U.K, 170-188.

Morato, T., Hoyle, S.D., Allain, V., Nicol, S.J. (2010). Seamounts are hotspots of pelagic biodiversity in the open ocean. PNAS, 107 (21): 9707-9711

Mossop, J. (2017). The relationship between the continental shelf regime and a new international instrument for protecting marine biodiversity in areas beyond national jurisdiction. ICEA J. Mar. Sci. DOI:10.1093/icesjms/fsx111

Obura, D.O., Church, J.E., Gabrié, C. (2012). Assessing Marine World Heritage from an Ecosystem Perspective: The Western Indian Ocean. World Heritage Centre, United Nations Education, Science and Cultural Organization (UNESCO). 124 p. 
Parin, N.V., Nesis, K.N., Sagaidachny, A.Y., Shcherbachev, Y.N. (1993). Fauna of Walters Shoal, a seamount in the southwestern Indian Ocean. Trudy Institut Okanologii, 128: 199-216. [in Russian]

Panjarat, S., Boonsripum, C. (2018). National Annual Report: Thailand Reports to the SIOFA Scientific Committee. 3rd Meeting of the Southern Indian Ocean Fisheries Agreement (SIOFA) Scientific Committee 20-24 March 2018, Saint Denis, La Reunion. SC-0303(03). 15 p.

Pinet, P., Jaquemet, S., Phillips, R.A., Le Corre, M. (2012). Sex-specific foraging strategies throughout the breeding season in a tropical, sexually monomorphic small petrel. Anim. Behav., 83: 979-989.

Pitcher, T.J., Clark, M.R., Morato, T., Watson, R. (2010). Seamount fisheries: do they have a future? Oceanography 23: 134-144.

Popova, E., Vousden, D., Sauer, H., Essam, Y. M., Allain, V., Downey-Breedt, N., Fletcher, R., Gjerde, K.M., Halpin, P.N., Kellya, S., Obura, D., Pecl, G., Roberts, M., Raitsos, D. R. , Rogers, A., Samoilys, M. Rashi,d U.S., Tracey S., Yool A. (2019), Ecological connectivity between the areas beyond national jurisdiction and coastal waters: Safeguarding interests of coastal communities in developing countries, Marine Policy,Volume 104: 90-102.

Reeves, C. (2014). The position of Madagascar within Gondwana and its movements during Gondwana dispersal. Journal of African Earth Sciences, 94: 45-57.

Richer de Forges, B., Koslow, J.A., Poore G.C.B. (2000). Diversity and endemism of the benthic sea-mount fauna in the southwest Pacific. Nature, 405: 944-947.

Roberts, C.M. (2002). Deep impact: the rising toll of fishing in the deep sea. Trends in Ecol. Evol., 17: 242-245.

Rogers, A. D. (1994). The biology of seamounts. Advances in Marine Biology, 30, 305-350.

Rogers, A.D. (2018). The biology of seamounts: 25 years on. Advances in Marine Biology, 79: 137-224. DOI: 10.1016/bs.amb.2018.06.001

Romanov, E.V. (2003). Summary and review of Soviet and Ukrainian scientific and commercial fishing operations on the deepwater ridges of the southern Indian Ocean. FAO Fisheries Circular. No. 991. Rome, FAO. 84p. 
Rowden, A.A., Schlacher, T.A., Williams, A., Clark, M.R., Stewart, R., Althaus, F., Bowden, D.A., Consalvey, M., Robinson, W., Dowdney, J. (2010). A test of the seamount oasis hypothesis: seamounts support higher epibenthic megafaunal biomass than adjacent slopes. Mar Ecol 31: 95-106.

Salazar-Vallejo, S.I. (2003). Revision of Synelmis Chamberlin, 1919 (Annelida, Polychaeta, Pilargidae). Zoosystema, 25(1): 17-42.

Samadi, S., Bottan, L., Macpherson, E., Richer de Forges, B., Boisselier, M-C. (2006). Seamount endemism questioned by the geographic distribution and population genetic structure of marine invertebrates. Mar Biol 149: 1463-1475.

Sauter D., Cannat M. (2010). The ultraslow spreading Southwest Indian Ridge. In: Rona P.A., Devey C.W., Dyment J., Murton B.J. Diversity of Hydrothermal Systems on Slow Spreading Ocean Ridges. Geophysical Monograph Series 188: 153-173.

Shotton, R. (2006). Management of demersal fisheries resources of the Southern Indian Ocean. FAO Fish. Circular 1020, 90 p.

Sigwart, J.D., Chen Chong, Thomas E.A., Allcock, A.L., Böhm, M., Seddon, M. (2019). Red listing can protect deep-sea biodiversity. Nature Ecol and Evol. DOI: 10.1038/s41559$\underline{019-0930-2}$

SIOFA (2019). Report of the Fourth session of the Scientific Committee (SC4), 25-29 March 2019, Yokohama, 195 p.

Sissenwine MP, Mace PM. (2007). Can deep water fisheries be managed sustainably? Report and documentation of the Expert Consultation on Deep-Sea fisheries in the High Seas. FAO Fish. Rep. 838: 61-111

Sorby, S. (2018). From universal to local law: prospects for the protection of whales in the western Indian Ocean through the Whale Route project, WIO Journal of Marine Science Special Issue 1/ 2018 75-83, Original Article 75.

Thoma, J., Pante, E., Brugler, M., France, S. (2009). Deep-sea octocorals and antipatharians show no evidence of seamount-scale endemism in the NW Atlantic. Mar. Ecol. Progr. Series 397: 25-35.

Trudelle, L., Cerchio, S., Zerbini, A.N., Geyer, Y., Mayer, F-X., Jung, J-L, Hervé, M.R., Pous, S., Sallée, J-B., Howard, C. (2016). Influence of environmental parameters on 
movements and habitat utilization of humpback whales (Megaptera novaeangliae) in the Madagascar breeding ground. R. Soc. open sci. 3: 160616. Doi:10.1098/rsos.160616

Watling L, Auster PJ (2017). Seamounts on the high seas should be managed as vulnerable marine ecosystems. Frontiers in Marine Science, 4, doi:10.3389/fmars.2017.00014

Worm, B., Lotze, H. K., \& Myers, R. A. (2003). Predator diversity hotspots in the blue ocean. Proceedings of the National Academy of Sciences of the United States of America, 100(17), 9884-9888.

Wessel, P. (2007). Seamount characteristics. In Pitcher, T.J., Morato, T., Hart, P.J.B., Clark, M.R., Haggan, N., Santos, R.S. (Eds.), Seamounts: Ecology, Fisheries \& Conservation 12. Blackwell Publishing, Oxford, U.K, 3-25.

Wright, G., Rochette, J., Gjerde, K., Seeger, I. (2018). The long and winding road: negotiating a treaty for the conservation and sustainable use of marine biodiversity in areas beyond national jurisdiction, IDDRI, Studies $\mathrm{N}^{\circ} 08 /, 18$ 2018, p. 82.

Yesson, C., Clark, M.R., Taylor, M.L., Rogers, A.D. (2011). The global distribution of seamounts based on 30 arc seconds bathymetry data. Deep-Sea Research Part I: Oceanographic Research Papers, 58(4), 442-453. doi: 10.1016/j.dsr.2011.02.004 


\section{List of figures}

910

911

912

913

914

915

916

917

918

919

920

921

922

923

924

925

926

927

928

929

930

931

932

933

934

935

936

937

Fig.1 - Bathymetric map of the West Indian Ocean showing the Mascarene Ridge with Saya de Malha, the Mozambique Plateau, the Madagascar Ridge with Walters Shoal, the South West Indian Ridge and other topographic features, as well as EEZ boundaries. Isobaths of $2000 \mathrm{~m}$ and shallower depths are denoted with a black contour. Map generated from the ETOPO1 Global relief Model.

Fig. 2- Deep-sea fishes catches in the Southern Indian Ocean (source: FAO 2017 FishStat)

Fig. 3 - Five official sites of seamounts classified as SIOFA Protected Area (Fishery closures) during the 5Th MoP of SIOFA (29 June 2018). The seamounts are located in the international space in 2019, beyond the outer limits of the legal continental shelf, simple or extended, (Walters Shoal, Coral, Middle of What (MoW), Atlantis Bank, Fools Flat). The white squares represent the size of each protected area.

Fig.4 - Bathymetric map of Walters Shoal highlighting the presence of several submerged flat terraces and of large scars related to the submarine instabilities. Data acquired in 2017 during the MD208-Walters Shoal cruise (DOI: 10.17600/17002700).

Fig. 5 - Facies of the Walters Shoal's summit (A) with the main occurrences of red encrusting algae (Corallines, B, C), brow algae (Lobophora, C) and comatulids (Comanthus sp., D).

Fig 6 - Bathymetry of the Walters Shoal region showing the Madagascar Ridge and the Mozambique Plateau (source: ETOPO1 Global relief Model, https://www.ngdc.noaa.gov/ mgg/global/global.html) with the EEZ and the theoretical $350 \mathrm{M}$ limit (white dotted line), along with four proposals of conservation perimeters according bathymetric criteria (Source: Demarcq \& Galletti, IRD)

Fig. 7 - Map showing the submission by Madagascar to CLCS regarding the extension of its continental shelf (21 April 2011). Source: http://www.un.org/depts/los/clcs_new/ clcs_home.htm 
938

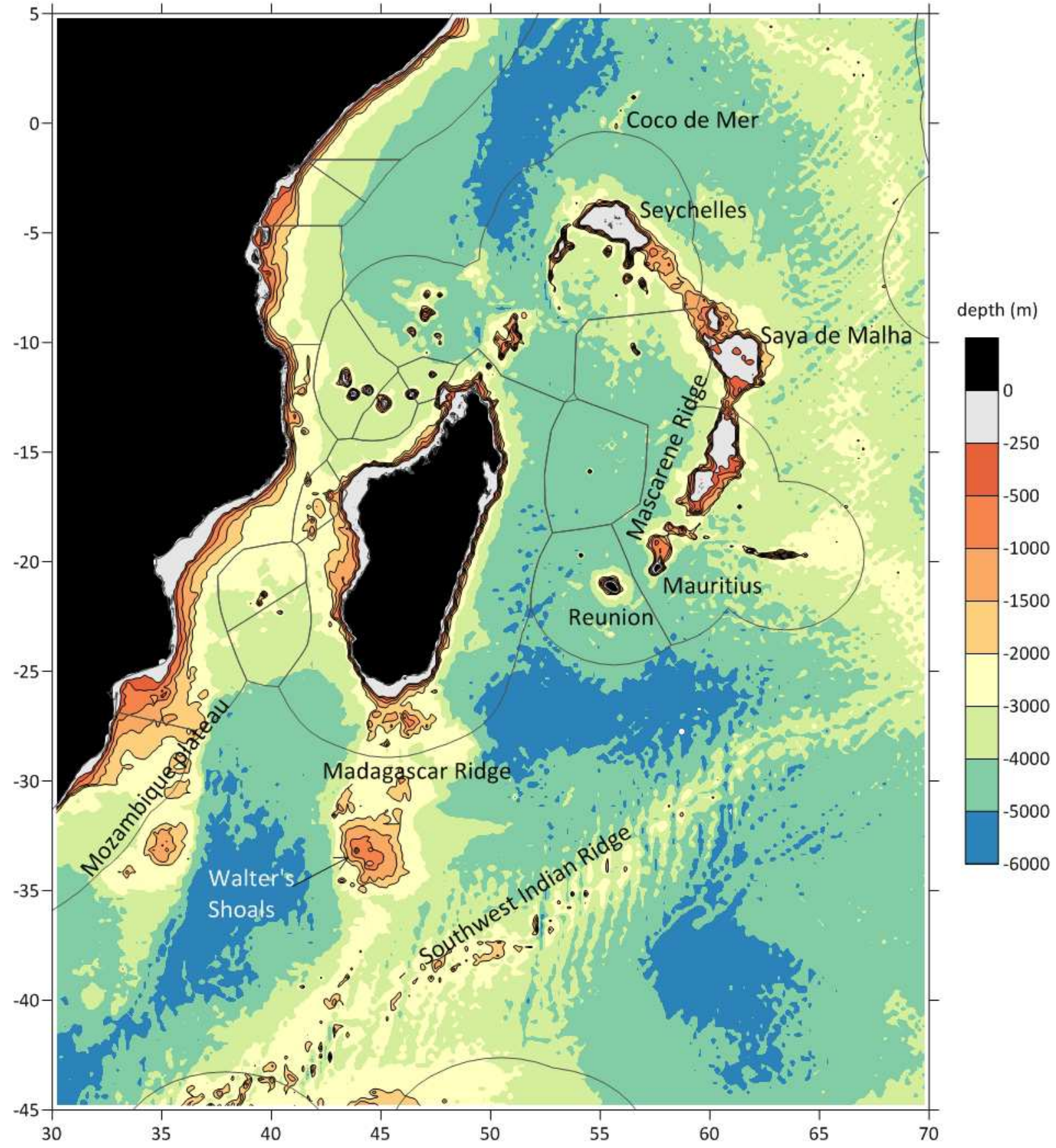




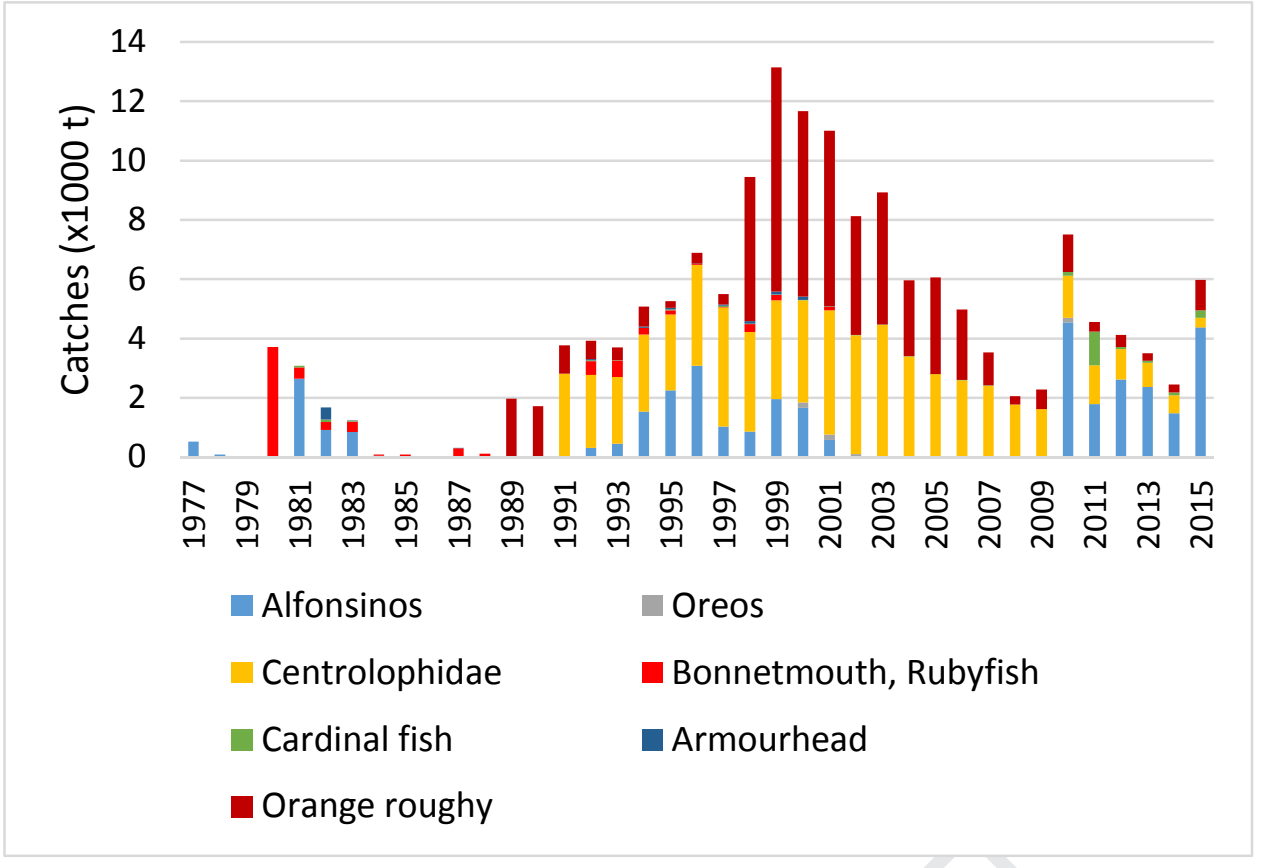


956

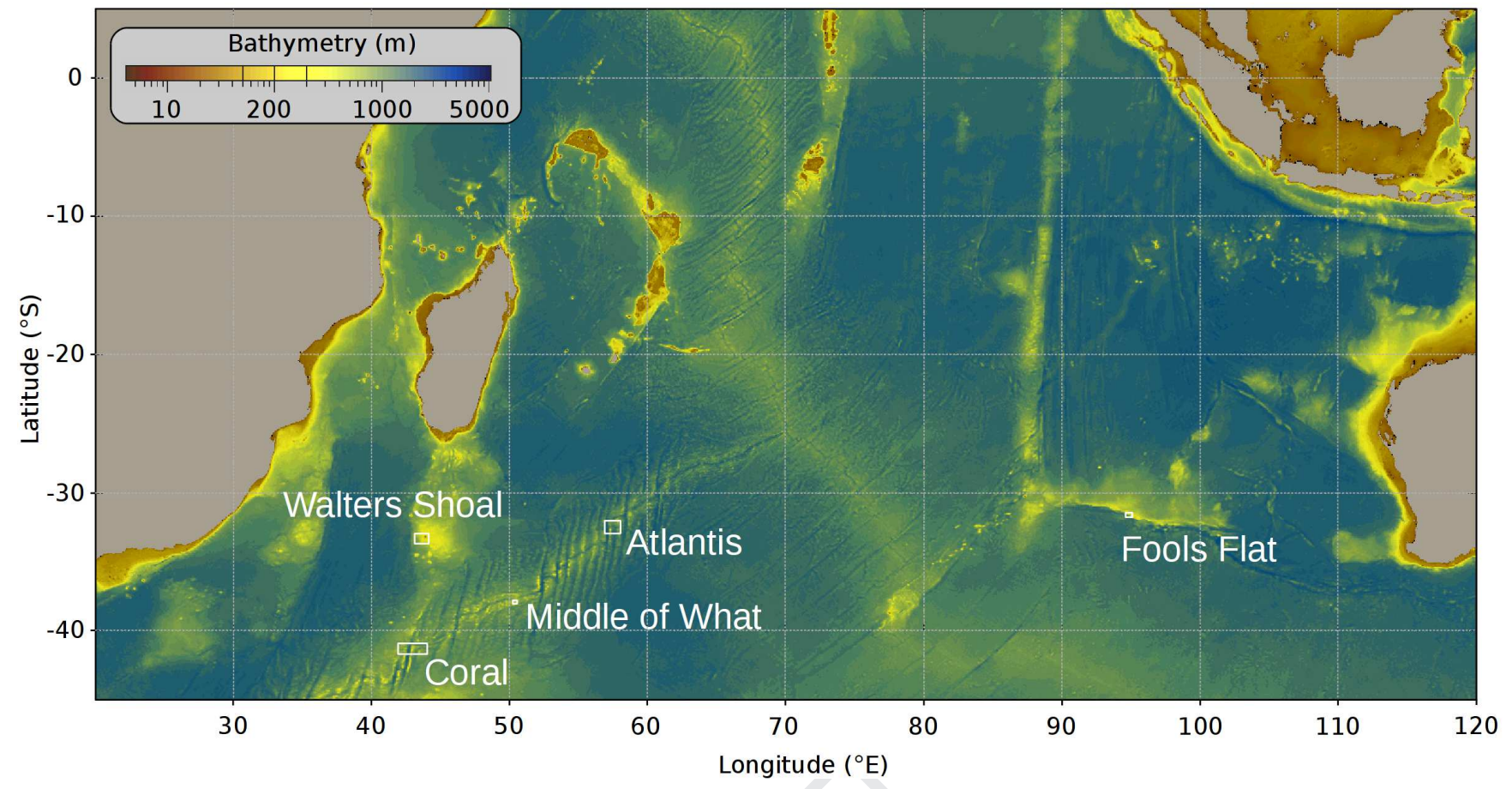

957

958

959

960

961

Figure 3

962 
963

964

965

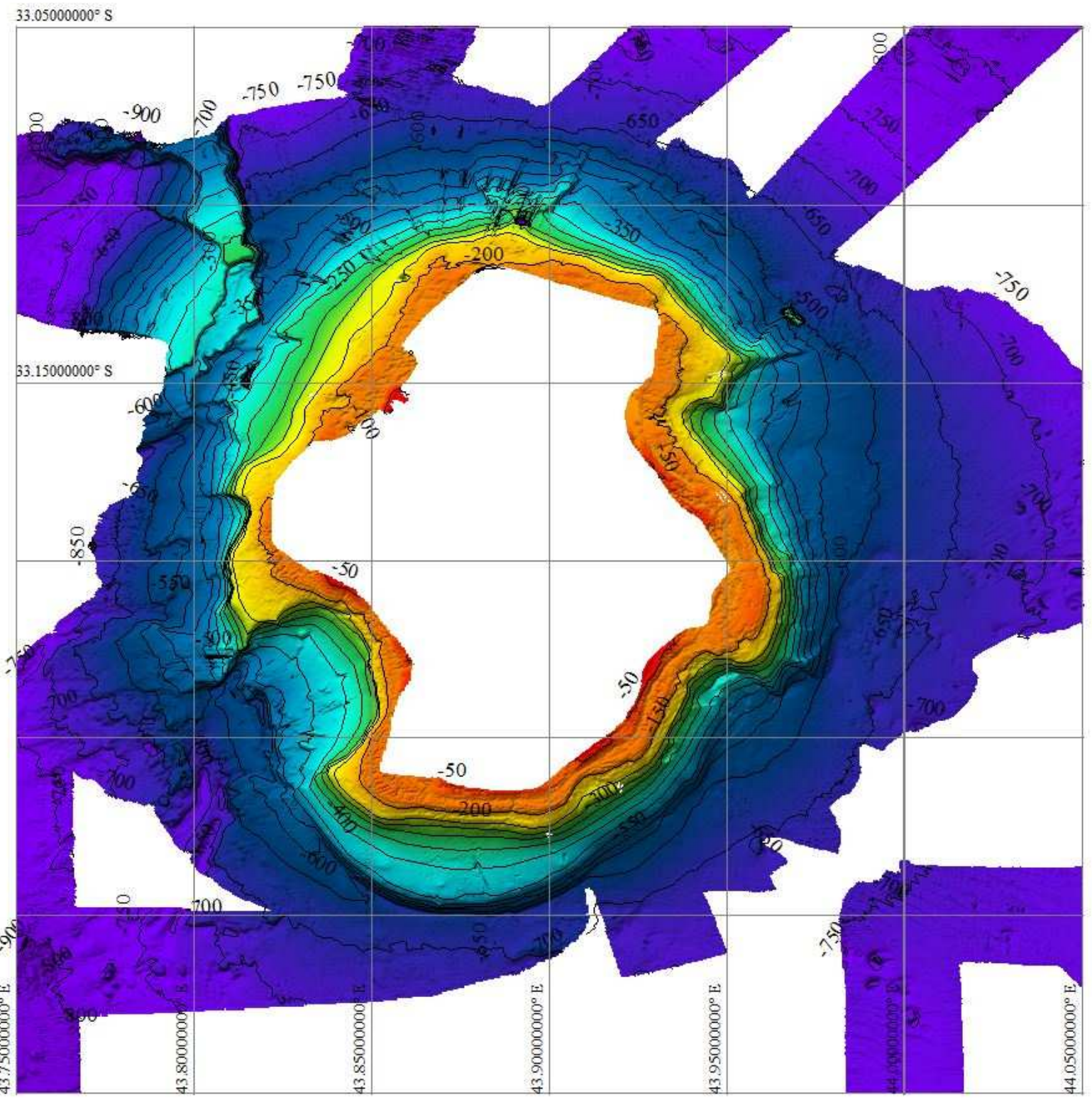

966

967

968

969

970

971

972

Figure 4

973 

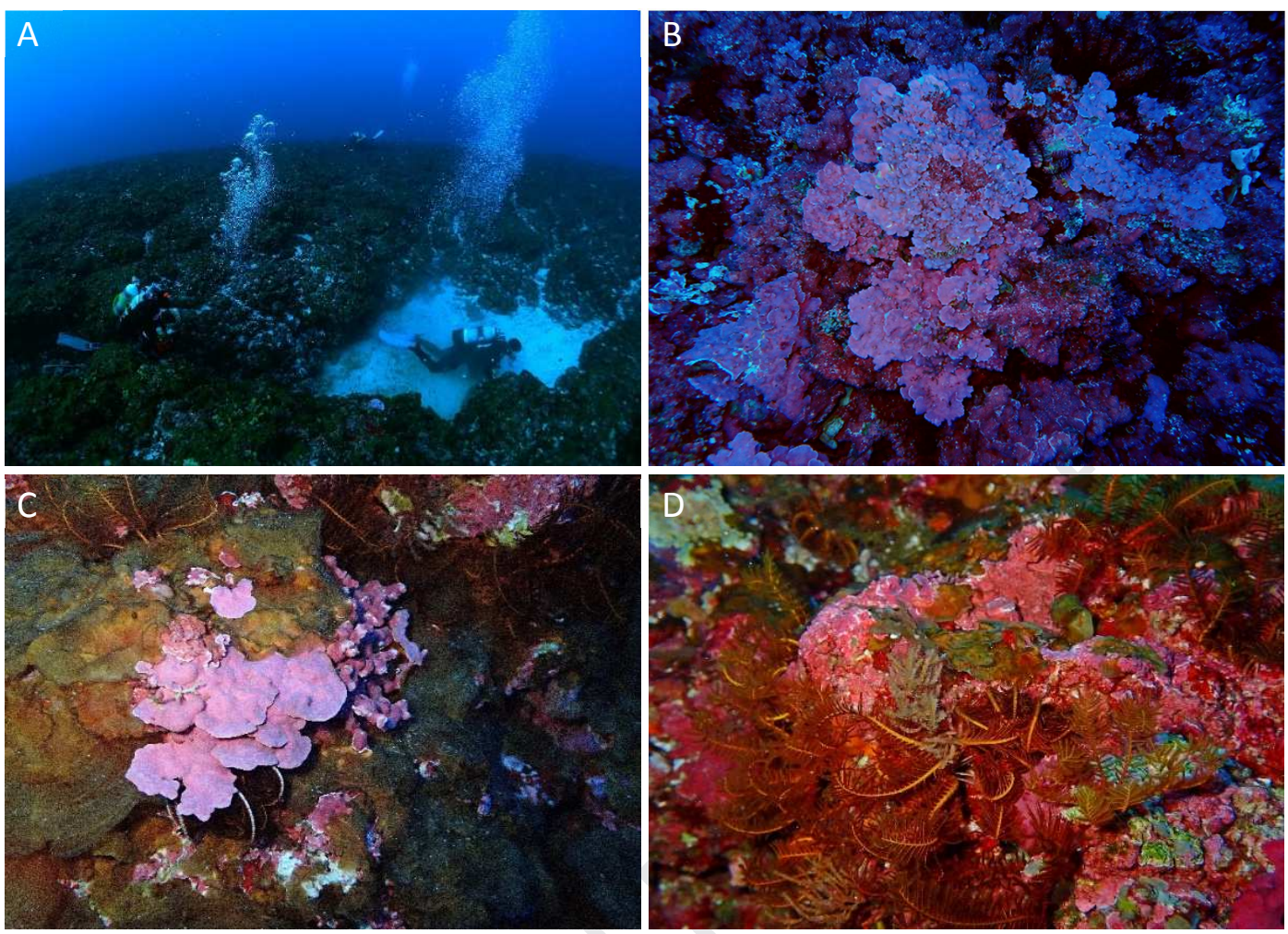

976

977

978

979

980

Figure 5

981

982 
983

984

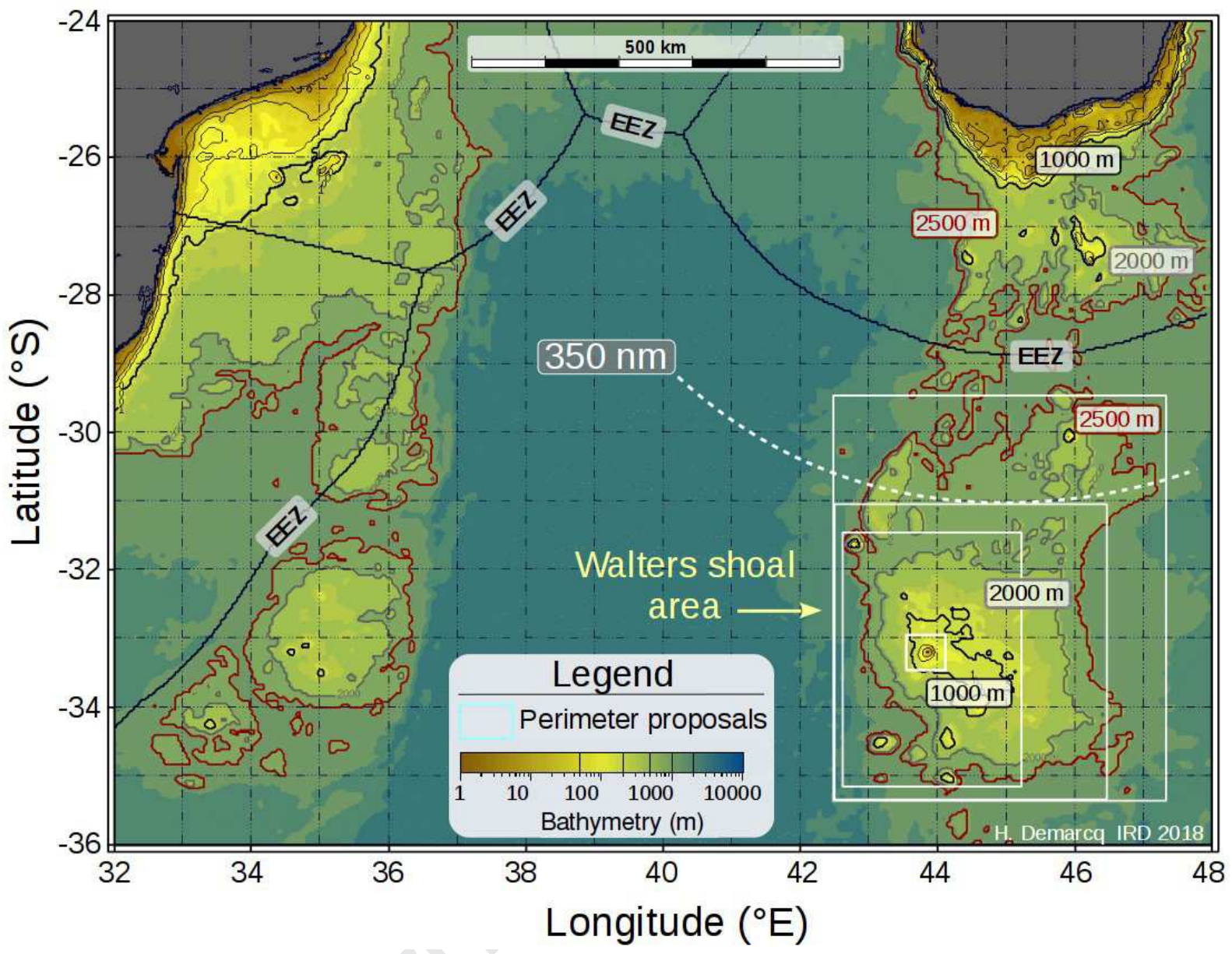

985

986

987

988

989

990

Figure 6 
991

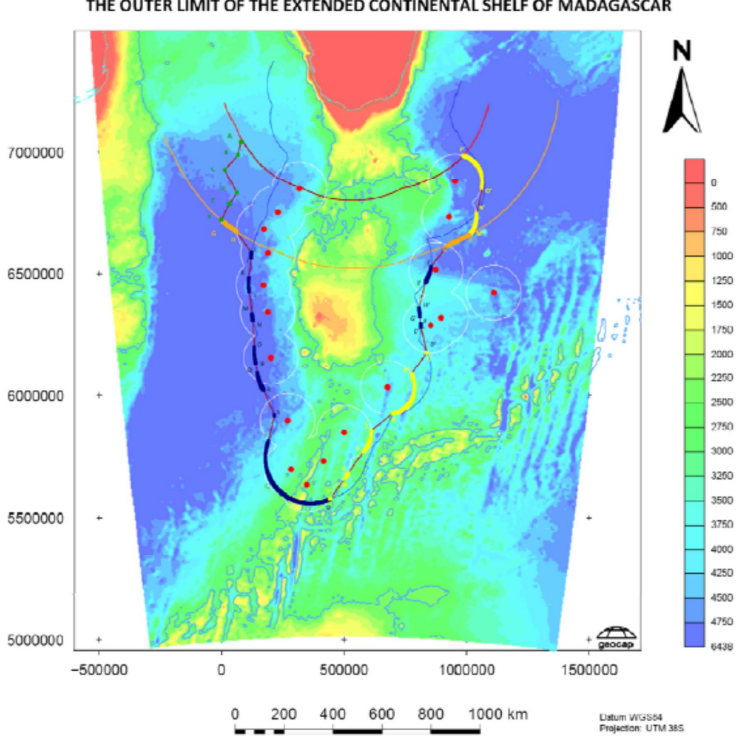

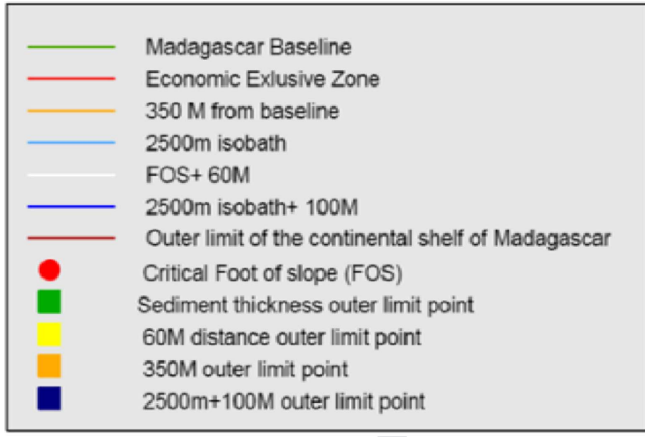




\section{Declaration of interests - ms \#108}

$\bigotimes$ The authors declare that they have no known competing financial interests or personal relationships that could have appeared to influence the work reported in this paper.

$\square$ The authors declare the following financial interests/personal relationships which may be considered as potential competing interests: 